\title{
Making use of geothermal brine in Indonesia: binary demonstration power plant Lahendong/Pangolombian
}

\author{
Stephanie Frick, Stefan Kranz , Gina Kupfermann, Ali Saadat and Ernst Huenges
}

*Correspondence:
kranz@gfz-potsdam.de
Helmholtz Centre Potsdam-
GFZ German Research Centre
for Geosciences, Section 4.8
Geoenergy, Potsdam,
Germany

${ }^{*}$ Correspondence: kranz@gfz-potsdam.de GFZ German Research Centre for Geosciences, Section 4.8 Germany

\begin{abstract}
This paper describes a novel concept for integrating binary plants at a geothermal site which has been realized within a demonstration project in Indonesia. By using an intermediate hot water and an intermediate cooling water cycle it is possible to integrate a fully-automated binary plant with flexible operation in an existing, predominantly manually operated geothermal field. The paper gives technical component details and describes specific design considerations of the demonstration power plant. Furthermore operational data and experiences are shared. Current binary plant operation is characterized by many starts and stops because of several technical challenges, e.g. electrical grid conditions, as well as by off-design conditions. The proven maximum power capacity until now is approximately $400 \mathrm{~kW}$. By means of a numerical model it is shown that the design capacity of $500 \mathrm{~kW}$ can be reached.
\end{abstract}

Keywords: Binary plant, ORC, Demonstration, Lahendong

\section{Introduction}

Indonesia is known for its tremendous geothermal potential of around $29 \mathrm{GW}_{\mathrm{e}}$ which is dominated by wet steam fields. The currently installed capacity amounts to $2 \mathrm{GW}$ from 15 areas (Darma 2016; Richter 2018a), leaving a significant amount of the geothermal potential untapped. Considering the continuously increasing need for electricity in Indonesia, there are strong efforts to further develop the geothermal power capacity.

The prevailing geothermal plant type in Indonesia is currently the single-flash plant which directly uses the steam phase from the produced steam-liquid-mixture to drive the turbine. Binary plants which transfer the geothermal heat to a separate working fluid are not yet an established technology at Indonesian sites. The first commercial binary units were commissioned at Sarulla field in 2017 (Wolf and Gabbay 2015; Richter 2018b) although due to their adaptability they could be implemented at much more sites and increase the geothermal capacity in Indonesia. Binary power plants can extend the plant capacity at high enthalpy fields but can also be used to exploit low to intermediate temperature geothermal reservoirs and realize small scale geothermal power plants.

In order to successfully demonstrate geothermal binary power plant technology at an Indonesian site and to intensify the know-how transfer in this technology field, a German-Indonesian collaboration project was initiated in 2013 between GFZ Potsdam

(c) The Author(s) 2019. This article is distributed under the terms of the Creative Commons Attribution 4.0 International License (http://creativecommons.org/licenses/by/4.0/), which permits unrestricted use, distribution, and reproduction in any medium, provided you give appropriate credit to the original author(s) and the source, provide a link to the Creative Commons license, and indicate if changes were made. 
(Germany), the Agency for the Assessment and Application of Technology in Indonesia (BPPT) and PT Pertamina Geothermal Energy (PGE). The project was based on a bilateral agreement between the German and the Indonesian Ministry of Research (Erbas et al. 2015).

The demonstration plant is located in the Lahendong geothermal area close to the village Pangolombian in the northern part of the island of Sulawesi. The first $20 \mathrm{MW}$ single-flash unit in this area has been commissioned in 2001. Meanwhile six $20 \mathrm{MW}$ units are in operation. The on-site construction phase of the demonstration plant, which is rated with a capacity of $500 \mathrm{~kW}$, started in 2015 (Frick et al. 2015). Technical concept development, component specification, coordination and supervision of the detail planning as well as construction and commissioning were executed by the project consortium under the guidance of GFZ. The operational phase commenced in September 2017. In January 2019 the demonstration plant was handed over to the Indonesian consortium and is now operated and maintained by the Indonesian project partners. Besides commercial operation the plant will be used for demonstration activities and training.

This paper describes the technical concept and summarizes the first operational experiences of the demonstration plant that has been integrated at an already existing site. With this plant concept it was possible to realize a fully-automated binary plant concept with flexible operation in an existing, predominantly manually operated geothermal field.

\section{State of knowledge}

Geothermal binary plants use different concepts of site integration. Binary plants complement the direct steam use at a geothermal high enthalpy site by either using the liquid phase from the separator or by utilizing the waste heat from the direct-steam turbine. Geothermal binary plants can also use the complete fluid flow from a geothermal highor medium-enthalpy field and process the heat contained in the hot water from deep hydrothermal resources.

A comprehensive overview on geothermal binary power plants is given by DiPippo (2015). A description of the technical status-quo of binary plant technology can also be found in Bronicki (2013). Geothermal binary plants are in most cases Organic Rankine Cycle (ORC) plants, which are directly driven by the geothermal heat and which are often realized as single-stage and sub-critical processes. Depending on the plant capacity and the site conditions power plants with multiple heat input, multi-stage cycles and cycles with internal heat recovery can be found (DiPippo 2015; Agahi and Valdimarsson 2015; Heberle et al. 2015). Commonly used working fluids are Isobutane, Isopentane, R245fa, R134a, $n$-Butane and $n$-Pentane. Referring to plants with a capacity of $100 \mathrm{~kW}_{\mathrm{e}}$ and above, a water-ammonia-mixture (so called Kalina cycle) is currently only used at one site in Germany.

When realizing binary power plants different technical decisions have to be made. Important topics are working fluid selection, process design as well as turbine and heat exchanger specification (e.g. Lakew and Bolland 2010; Gao et al. 2012; Maraver et al. 2014; Toffolo et al. 2014; Walraven et al. 2014). Many authors therefore agree that a thermodynamic analysis is not sufficient and that a techno-economic evaluation based on different criteria is necessary. Different approaches for techno-economic design point 
evaluation are presented and discussed by Hettiarachchi et al. (2007), Quloilin (2011), Shengjun et al. (2011), Cataldo et al. (2014), Li et al. (2014) and Astolfi et al. (2014).

A specific design constraint for designing geothermal binary power plants is the limitation for the cooling of the geothermal fluid in order to avoid scaling (Franco 2011; Bronicki 2013; Wendt and Mines 2010) or in order to realize hot fluid reinjection close to the production wells (Noorollahi and Itoi 2011). Another important aspect is the consideration of changing or variable operating conditions. Sanyal et al. (2005), Gabbrielli (2012) and Budisulistyo et al. (2017) discuss possible design strategies to deal with the degradation of the geothermal resource over the lifetime of the plant. Astolfi et al. (2011), Manente et al. (2011) and Usman et al. (2017) address the effect of variable ambient conditions when using direct air-cooled condensers (ACC). Astolfi et al. (2019) investigate in this context the implementation of an intermediate cooling water cycle in order to use both, a compact water-cooled condenser and a flexibly operable dry cooler.

This paper gives details on the technical components and describes specific design considerations of a demonstration power plant that is equipped with both, intermediate cooling water and intermediate hot water cycle. Furthermore, this paper presents a numerical model that has been developed based on the technical component specifications and real plant data in order to predict the power output of the demonstration plant for varying hot water and ambient conditions.

\section{Technical concept and design data}

The demonstration plant has been integrated at the Lahendong geothermal field close to the village Pangolombian where geothermal brine with a temperature of about $170{ }^{\circ} \mathrm{C}$ corresponding to a separator pressure of $7.9 \mathrm{bar}_{\mathrm{a}}$ was available. The cooling of the brine should be limited to $140{ }^{\circ} \mathrm{C}$ in order to have the possibility for hot brine reinjection close to the production well. The brine composition was reported with a $\mathrm{SiO}_{2}$-concentration between 100 and $500 \mathrm{mg} / \mathrm{l}$, a pH-value between 5 and 9 and a TDS-content (total dissolved solids) between 150 and $540 \mathrm{mg} / \mathrm{l}$. More details for Lahendong geothermal area can be obtained from Nugroho and Andi (2007), Koestono et al. (2010), Brehme et al. (2014), Brehme et al. (2016a, b). Based on the available project budget the electrical capacity was rated with $500 \mathrm{~kW}$ so that the necessary brine flow rate was estimated with 30 to $35 \mathrm{~kg} / \mathrm{s}$. Cooling water was not available.

To be able to handle a broad range of brine compositions and operate the binary plant with variable capacity without changing the brine supply as well as meeting project specific constraints (e.g. pretesting of the ORC-prototype in Germany), it was decided to integrate the power conversion cycle by using intermediary closed water cycles for heat supply and heat removal. Aiming for high reliability, a subcritical, single-stage ORC with internal heat recovery was chosen as the conversion cycle. $N$-Pentane, a well-known working fluid suitable for the heat source temperature at the demonstration site, was selected as the working fluid. The process diagram is shown in Fig. 1. Solid lines indicate normal operation. Dotted lines indicate operation during start-up or shut-down of the demonstration plant.

During normal operation, the heat of the brine is transferred to the hot water cycle using the primary heat exchanger. The hot water is then used to heat and evaporate the working fluid inside the ORC-unit. The hot water is continuously circulated by using 


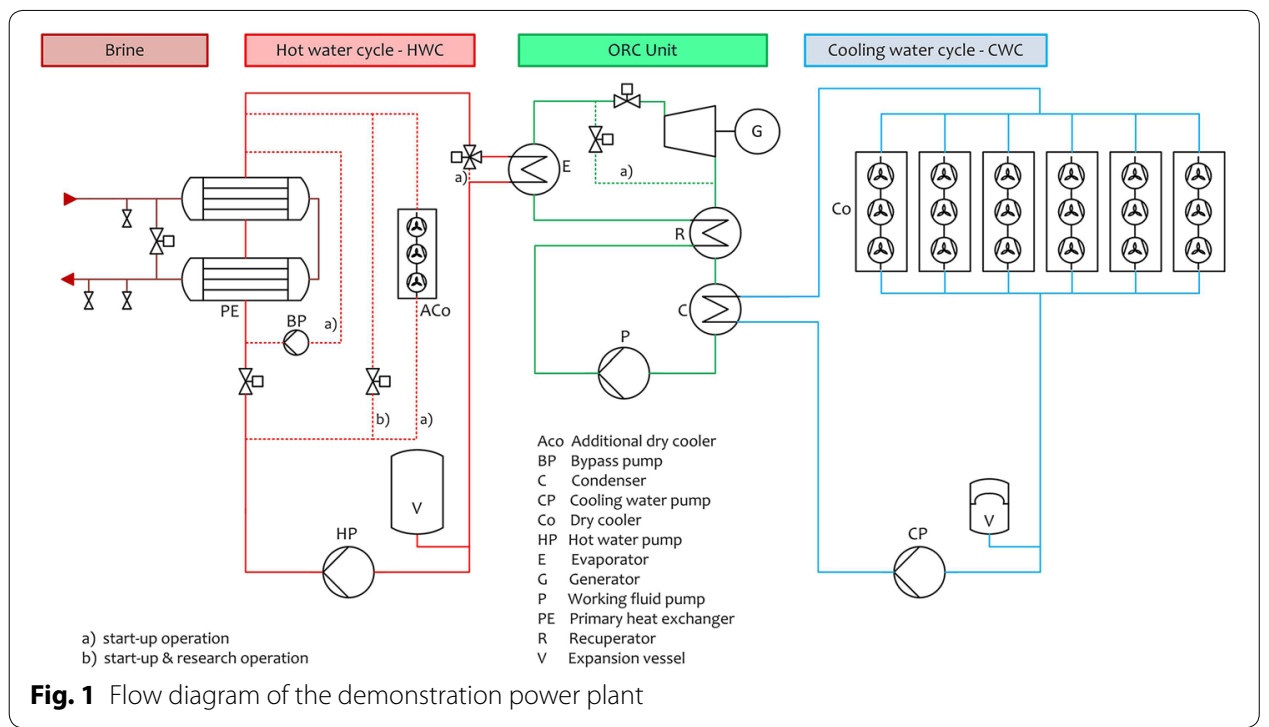

a centrifugal pump. In order to keep the pressure in the hot water cycle in a defined operating range, an expansion vessel with nitrogen cushion is used. In the ORC-unit the working fluid vapor drives a turbogenerator. After the turbine, the superheated working fluid vapor flows through a recuperator register before getting in touch with the watercooled tubes. The heat removal in the cooling water cycle is realized with a dry cooler consisting of 6 units.

Using intermediary water cycles, the net power output is decreased due to the additional heat resistance and the additional power consumption of the pumps. The net power loss caused by the hot water cycle has been estimated with about $13 \%$ and the loss caused by the cooling water cycle with about $11 \%$, both compared to a plant without intermediary cycles. However, the intermediary water cycles were realized in this project due to practical advantages which are described below.

Using a hot water and a cooling water cycle it was possible to transport and install a completely preassembled and pretested ORC-unit. Using the hot water cycle, it was further possible to operate, shut-down and start-up the binary plant without changing the existing operational regime of the brine supply. The used prototype ORC-unit can only be started at low supply temperatures since large temperature differences between hot water and the working fluid can lead to steam hammer in the evaporator. Therefore, an additional dry cooler is necessary to cool down the hot water before restart and the control valves are used to realize a defined temperature ramp. The hot water by-pass pump is implemented to realize modest temperature differences around the primary heat exchanger during restart and to reduce the risk of steam hammer on the brine side.

Another advantage of the hot water cycle is that different priorities can be applied for the heat exchanger design. Regarding the primary heat exchanger, which transfers the heat from the brine to the hot water, the accessibility of the tubes for cleaning procedures and corrosion resistant materials has a high priority. The evaporator design focuses instead on the heat transfer. An advantage of implementing the cooling water cycle is that design and operation of the dry cooler becomes easier due to the well-known single 


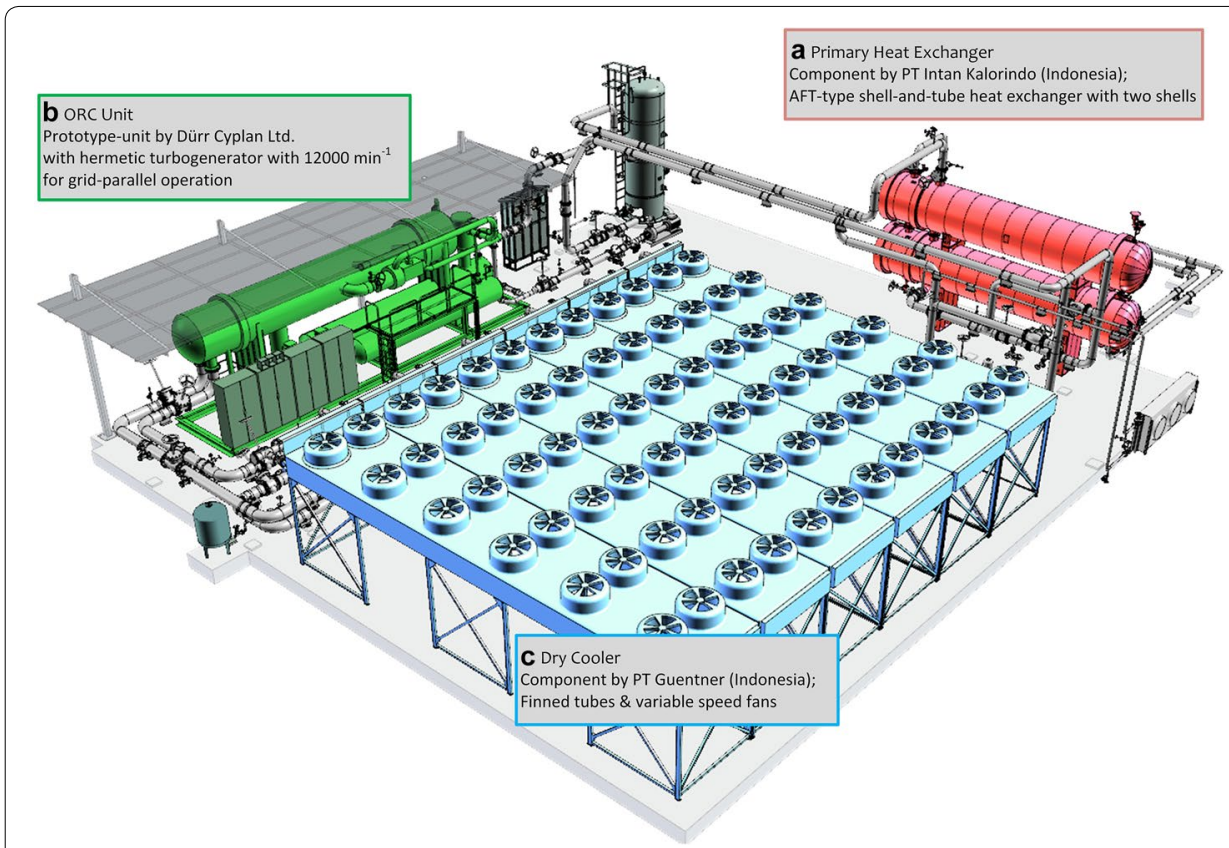

Fig. 2 3D-Plant layout showing primary heat exchanger (a), ORC-unit (b) and dry cooler (c)

phase heat-transfer of water. Furthermore, less working fluid is needed to fill the ORCcycle and the risk of n-pentane leakage is decreased. The practical advantages of an intermediary cooling water cycle are also addressed by Astolfi et al. (2019).

The 3D-layout is shown in Fig. 2. Table 1 lists the main equipment and its technical specification.

The main process design data are listed in Table 2. A $T$ - $\dot{Q}$-diagram is shown in Fig. 3. For the geothermal fluid supply, a design mass flow $\dot{m}_{\text {geo }}$ of $32 \mathrm{~kg} / \mathrm{s}$ was considered. Supply and return temperature $T_{\text {geo,i }}$ and $T_{\text {geo,o }}$ of the geothermal liquid were assigned with $172.5^{\circ} \mathrm{C}$ and $142.5^{\circ} \mathrm{C}$, respectively. The heat capacity rate of the hot water was adapted to the heat capacity rate of the geothermal fluid in order to minimize the exergy destruction in the primary heat exchanger. Due to the fact that the heat transfer area increases significantly with lower pinch points, the minimum temperature difference between geothermal fluid and hot water was set with $7 \mathrm{~K}$.

Using a relatively small temperature spread referring to the heat supply, the process design of the ORC-unit had to be adapted. From Fig. 4 it can be seen that the evaporation temperature delivering the maximum power output would lead to a hot water outlet temperature lower than $135{ }^{\circ} \mathrm{C}$. Hence the outlet temperature and not the power output was decisive for the selection of the evaporation temperature.

The condensation temperature of the ORC-unit was selected based on the maximum net power output considering the power consumption of the cooling water pump and the dry cooler fans. A lower condensation temperature leads to a higher gross power output but also higher fan power consumption. Figure 5 (left) shows the influence of the initial temperature difference $\Delta T_{\mathrm{ITD}}$, which is the difference between cooling water inlet temperature to the dry cooler $T_{\mathrm{CW}, \mathrm{o}}$ and air inlet temperature $T_{\mathrm{a}, \mathrm{i}}$, on the gross power and the fan power consumption. In Fig. 5 (right) the influence of the dry cooler size 
Table 1 Component specification of the demonstration plant

\begin{tabular}{|c|c|}
\hline Component & Description \\
\hline $\begin{array}{l}\text { Primary heat } \\
\text { exchanger }\end{array}$ & $\begin{array}{l}2 \times \text { Shell-and-tube heat exchanger with brine on the tube side and hot water }(\mathrm{HW}) \text { on } \\
\text { the shell-side; } 2 \times A F T \text {-types in series, heat transfer area: } 2 \times 310 \mathrm{~m}^{2} \text {, Thermal capac- } \\
\text { ity }=2 \times 2250 \mathrm{~kW} \\
\text { Heat transfer rate }=1100 \mathrm{~W} \mathrm{~m}^{-2} \mathrm{~K}^{-1}, \mathrm{LMTD}=7.1 \mathrm{~K} \\
\text { Each vessel with } 2 \text { passes on shell and tube side } \\
\text { Tube design: OD }=19.05 \mathrm{~mm} \text {, Thickness }=1.65 \mathrm{~mm} \text {, Length: }=6.1 \mathrm{~m} \text {, Pitch }=28.575 \text {, Tube } \\
\text { pattern: } 90, \text { Number }=2 \times 860 \\
\text { Shell side design: cross baffles, Cut }=21.2 \% \text {, Spacing }=598 \mathrm{~mm}, \text { Number }=9 \text { (each pass) } \\
\text { Design data tube side: flow rate }=35 \mathrm{~kg} / \mathrm{s} \text {, inlet temperature }=172.5^{\circ} \mathrm{C} \text {, outlet tempera- } \\
\text { ture }=142.5 \text {, pressure drop }=12 \mathrm{kPa} \\
\text { Design data shell side: flow rate }=35 \mathrm{~kg} / \mathrm{s} \text {, inlet temperature }=135^{\circ} \mathrm{C} \text {, outlet tempera- } \\
\text { ture }=165^{\circ} \mathrm{C} \text {, pressure drop }=23 \mathrm{kPa}\end{array}$ \\
\hline $\begin{array}{l}\text { Evaporator/pre- } \\
\text { heater }\end{array}$ & $\begin{array}{l}\text { Shell-and-tube heat exchanger with hot water on the tube side and working fluid on the } \\
\text { shell-side; staggered arrangement }\end{array}$ \\
\hline Recuperator & $\begin{array}{l}\text { Shell-and-tube heat exchanger with finned tubes: working fluid vapor on the shell-side and } \\
\text { liquid on the tube side }\end{array}$ \\
\hline Condenser & $\begin{array}{l}\text { Shell-and-tube heat exchanger with working fluid on the shell-side and cooling water (CW) } \\
\text { on the tube side }\end{array}$ \\
\hline Dry cooler & $\begin{array}{l}\text { Horizontal tube bundle with finned tubes, cooling water flow inside the tubes and forced } \\
\text { air flow across the tube bundle; forced air flow by means of variable speed fans } \\
\text { Heat exchange surface: } 6 \times 2999.8 \mathrm{~m}^{2} \\
\text { Surface reserve: } 26 \% \\
\text { Thermal capacity: } 6 \times 583.0 \mathrm{~kW} \\
\text { Design data air-side: Volume flow rate }=6 \times 157,127 \mathrm{~m}^{3} / \mathrm{h} \text {, Inlet temperature }=30^{\circ} \mathrm{C} \text {, Outlet } \\
\text { temperature }=43^{\circ} \mathrm{C} \\
\text { Design data tube-side: Volume flow rate }=6 \times 50.7 \mathrm{~m}^{3} / \mathrm{h} \text {, Inlet temperature }=49^{\circ} \mathrm{C} \text {, Outlet } \\
\text { temperature }=39^{\circ} \mathrm{C} \text {, Pressure loss }=0.28 \text { bar } \\
\text { Heat transfer coefficient: } 36.52 \mathrm{~W} \mathrm{~m}^{-2} \mathrm{~K}^{-1} \\
\text { Electrical power consumption: } 6 \times 5.88 \mathrm{~kW}\end{array}$ \\
\hline Turbogenerator & $\begin{array}{l}\text { Hermetic turbogenerator with radial-inflow, nozzle stage and axial outflow; rotational } \\
\text { speed } 12,000 \text { rpm }\end{array}$ \\
\hline $\begin{array}{l}\text { Working fluid } \\
\text { pump }\end{array}$ & $\begin{array}{l}\text { Magnetically coupled centrifugal pumps; two pumps in parallel, head }=214 \mathrm{~m} \text {, flow } \\
\text { rate }=2 \times 26 \mathrm{~m}^{3} / \mathrm{h}\end{array}$ \\
\hline Hot water pump & Variable speed centrifugal pump: Head $=25 \mathrm{~m}$, flow rate $=150 \mathrm{~m}^{3} / \mathrm{h}$ \\
\hline $\begin{array}{l}\text { Cooling water } \\
\text { pump }\end{array}$ & Variable speed centrifugal pump: Head $=16 \mathrm{~m}$, flow rate $=370 \mathrm{~m}^{3} / \mathrm{h}$ \\
\hline
\end{tabular}

Table 2 Process design data and design electrical data of the demonstration plant

\begin{tabular}{|c|c|c|c|c|c|c|}
\hline \multirow{2}{*}{ Brine supply } & \multicolumn{2}{|c|}{ Temperatures } & \multicolumn{2}{|c|}{ Mass flow rates } & \multicolumn{2}{|c|}{ Electrical power } \\
\hline & $T_{\text {geo,i }}{ }^{\circ} \mathrm{C}$ & 172.5 & $\dot{m}_{\mathrm{geo}}$ in $\mathrm{kg} / \mathrm{s}$ & 32.0 & & \\
\hline & $T_{\text {geo,o }}{ }^{\circ} \mathrm{C}$ & 142.5 & & & & \\
\hline \multirow[t]{2}{*}{ Hot water cycle } & $T_{H W, i}$ in ${ }^{\circ} \mathrm{C}$ & 165.0 & $\dot{m}_{\mathrm{HW}}$ in $\mathrm{kg} / \mathrm{s}$ & 32.0 & $P_{\mathrm{el}, \mathrm{HP}}$ in $\mathrm{kW}$ & 8.9 \\
\hline & $T_{H W, O}$ in ${ }^{\circ} \mathrm{C}$ & 135.0 & & & & \\
\hline \multirow[t]{4}{*}{ Cooling water cycle } & $T_{a, i}$ in ${ }^{\circ} \mathrm{C}$ & 25.0 & $m_{a}$ in $\mathrm{kg} / \mathrm{s}$ & 221.4 & $P_{\mathrm{el}, \mathrm{F}}$ in $\mathrm{kW}$ & 25.4 \\
\hline & $T_{a, o}$ in ${ }^{\circ} \mathrm{C}$ & 40.7 & & & & \\
\hline & $T_{C W, i}$ in ${ }^{\circ} \mathrm{C}$ & 34.0 & $\dot{m}_{\mathrm{CW}}$ in $\mathrm{kg} / \mathrm{s}$ & 86.1 & $P_{\mathrm{el}, \mathrm{CP}}$ in $\mathrm{kW}$ & 16.2 \\
\hline & $T_{\mathrm{CW}, \mathrm{O}}$ in ${ }^{\circ} \mathrm{C}$ & 44.0 & & & & \\
\hline \multirow[t]{2}{*}{ ORC-unit } & $T_{e v}$ in ${ }^{\circ} \mathrm{C}$ & 142.6 & $\dot{m}_{\mathrm{WF}}$ in $\mathrm{kg} / \mathrm{s}$ & 9.5 & $P_{\mathrm{el}, \mathrm{G}}$ in $\mathrm{kW}$ & 499.4 \\
\hline & $T_{c d}$ in ${ }^{\circ} \mathrm{C}$ & 49.4 & & & $P_{\mathrm{el}, \mathrm{P}}$ in $\mathrm{kW}$ & 23.4 \\
\hline Net power & & & & & $P_{\text {el, Net }}$ in $\mathrm{kW}$ & 425.5 \\
\hline
\end{tabular}

on the net power output and the optimum initial temperature difference are displayed. Based on the evaluation of different quotations with different dry cooler sizes, the dry cooler cross-flow section was defined to be $120 \mathrm{~m}^{2}$. 


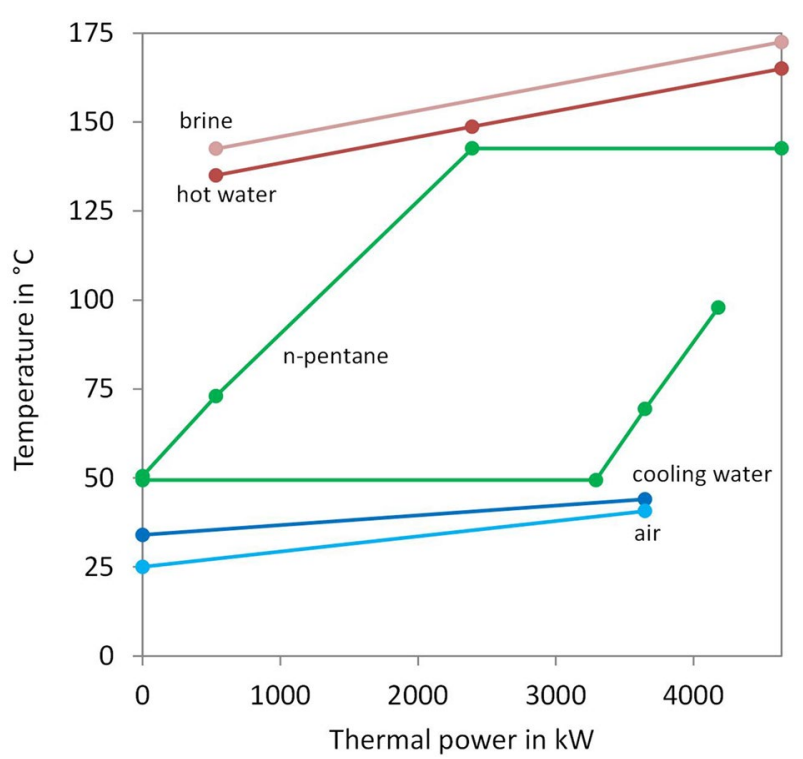

Fig. 3 T- $\dot{Q}$-diagram of the design point
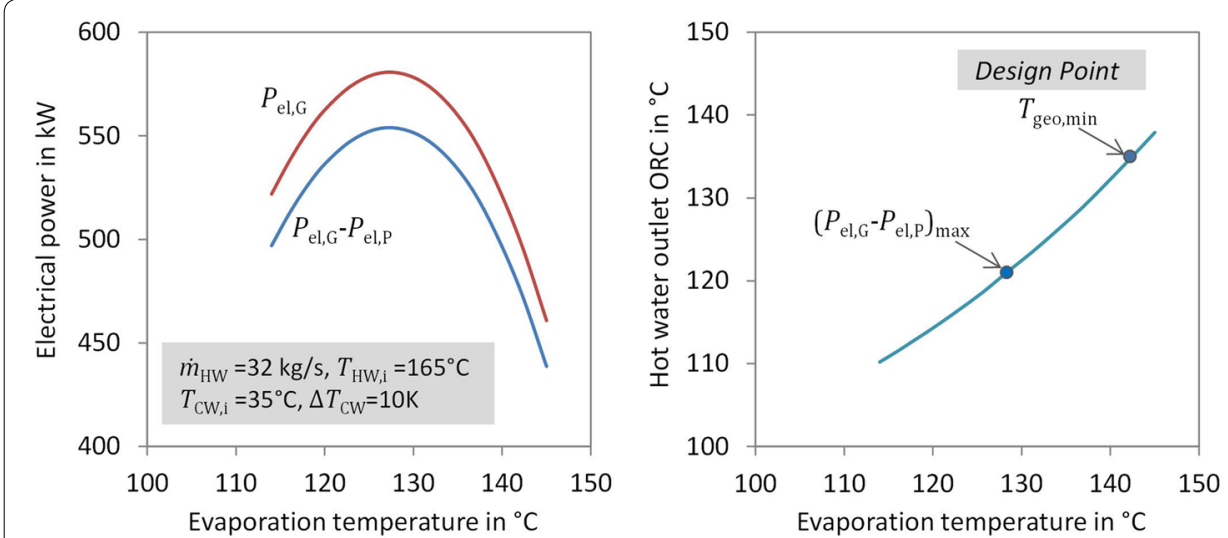

Fig. 4 Electrical power (left) and hot water outlet temperature (right) depending on the evaporation temperature

\section{Results and discussion}

\section{Operating experiences and plant operation}

The geothermal binary demonstration plant has been successfully operating since September 2017 and has produced more than $1.6 \mathrm{GWh}$ gross electricity and $1.3 \mathrm{GWh}$ net electricity as of April 2019. Since the commissioning several technical modifications have been realized in order to improve the plant reliability and availability. Firstly adaptations accounting for the high ambient humidity were realized. Secondly modifications of the prototype-turbogenerator, the hot water cycle and the plant control were necessary in order to manage frequent starts and stops of the plant which are caused by the electrical grid (mainly power outages, phase failure). The binary plant has been designed for grid-parallel and not for electrical island mode operation. 

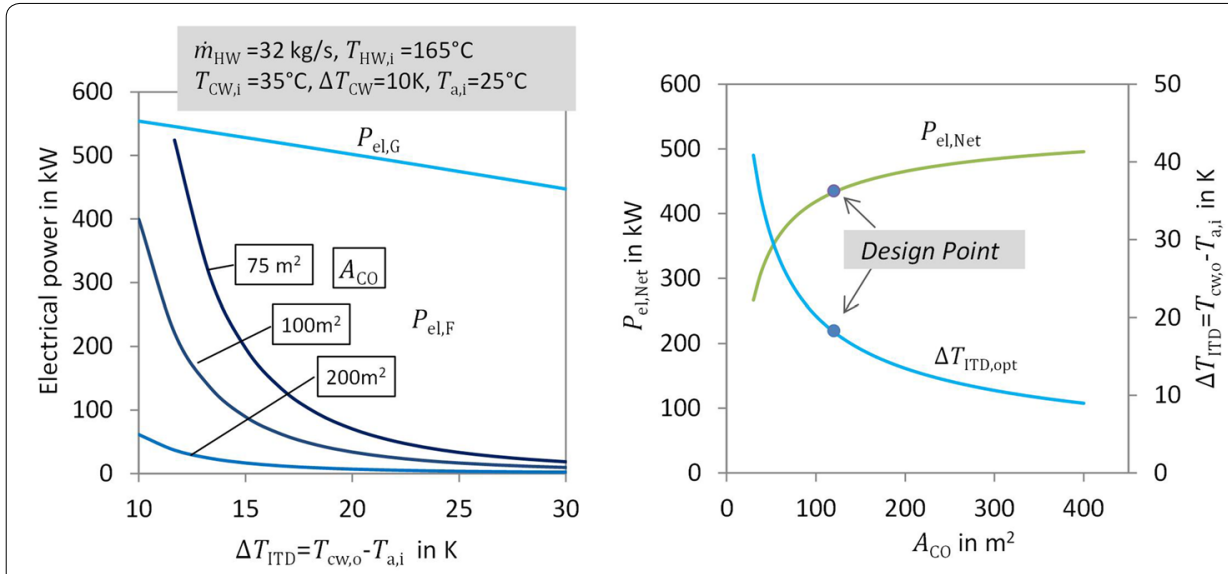

Fig. 5 Generator power and fan power depending on the initial temperature difference (left) and net power and optimal initial temperature difference depending on the dry cooler cross-section (right)

Based on the electrical grid quality data that where provided at the beginning of the project, it was not expected to have such a poor grid quality at the used grid connection point. Since September 2017 the plant has experienced more than 130 plant stops and starts. Furthermore, the real brine conditions made it necessary to modify some operating procedures. Instead of pure liquid as assumed for the design, a twophase flow is supplied to the binary plant. Both the well conditions and the operational regime of the separator have changed since the start of the project.

At the moment, the plant is operating with reduced power, which is sufficient to supply the injection pumps nearby. The operating power is thereby manipulated by controlling the hot water inlet temperature to the ORC unit with the automatic valves in the hot water cycle. The main reason for the power reduction is to reduce the wear on the turbogenerator bearing, which are most stressed during start-up and shutdown in the case of failure in the electrical grid.

Figure 6 shows the power production between March 2018 and April 2019. It can be seen that the plant stopped and started many times. Besides some maintenance work, most stops where caused by electrical grid failure. Figure 7 shows a 3-dayperiod in April 2019. It can be seen that gross power and net power show a daily fluctuation that is related to changing ambient temperatures (see Fig. 8). The cooling water supply temperature can be kept constant up to an ambient temperature of about $27{ }^{\circ} \mathrm{C}$ by means of variable speed fan operation. For higher ambient temperatures the fans are operated at full speed and the cooling water supply temperature follows the course of the ambient temperature. The stronger fluctuation of the net power is therefore caused by the changing ambient temperature and the variable fan power consumption.

In Fig. 9 the temperatures and pressures of the brine supply are shown in comparison to the saturation pressure of water. It can be seen that the supply pressure is very close to the saturation pressure and that there is only little cooling of the brine, both facts indicating two-phase flow into and liquid flow out of the primary heat exchanger.

Due to the operation at off-design conditions, the maximum proven gross power until now is $400 \mathrm{~kW}$. In order to evaluate the maximum power output of the demonstration 


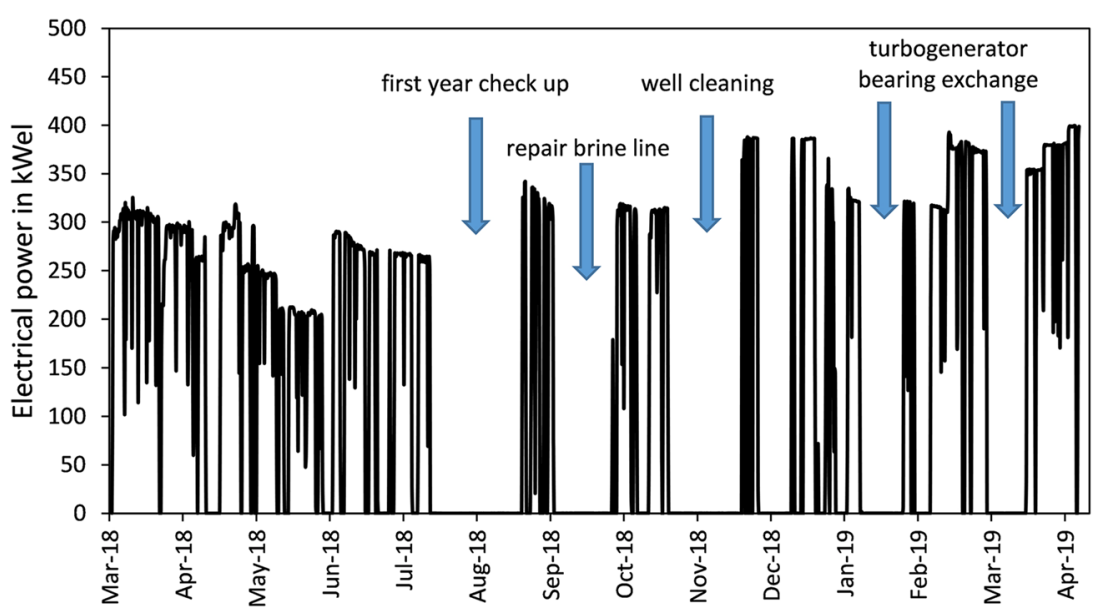

Fig. 6 Power output of the demonstration plant in 2018

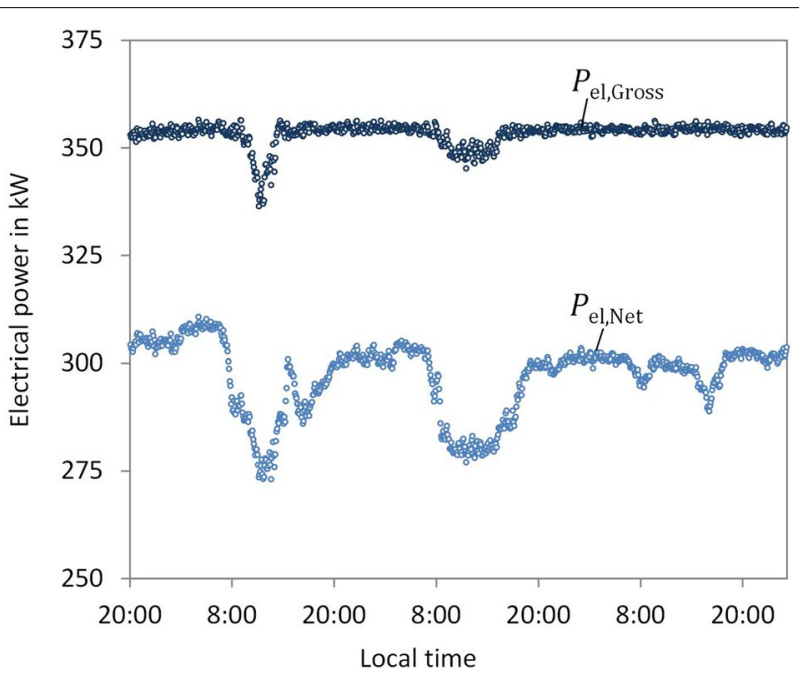

Fig. 7 Plant data for $48 \mathrm{~h}$ operation— gross and net power output

plant, a numerical plant model has been developed and is described in "Model-based power prediction" section.

\section{Model-based power prediction}

The plant model has been developed with the software environment Engineering Equation Solver $(E E S)^{1}$ and comprises the hot water cycle, the ORC-unit and the cooling water cycle. For modeling of the heat exchangers, heat transfer and pressure loss correlations from the VDI heat atlas have been used. The turbogenerator is represented as a turbine wheel with an upstream laval-nozzle stage. More detailed information on the model assumptions are presented in Table 3. 


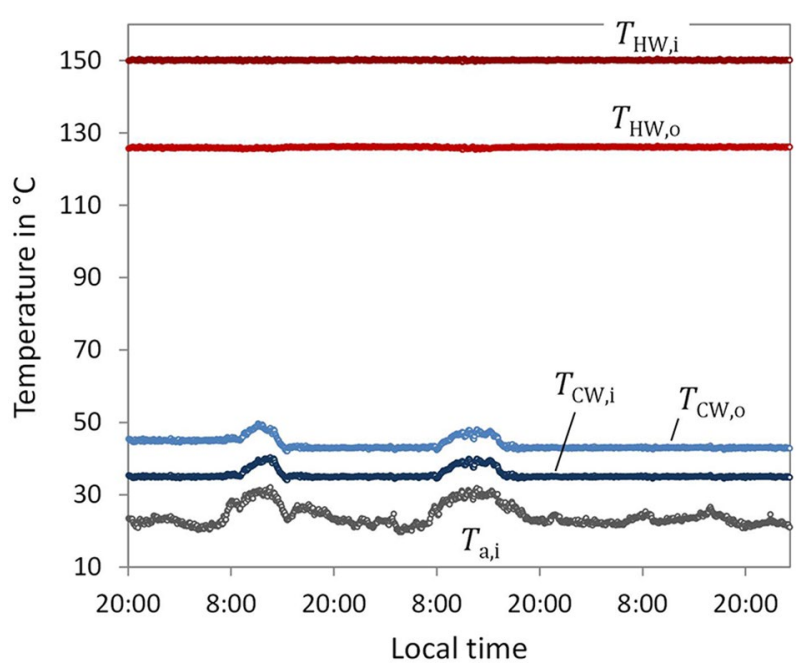

Fig. 8 Plant data for $48 \mathrm{~h}$ operation - temperatures heat supply and removal

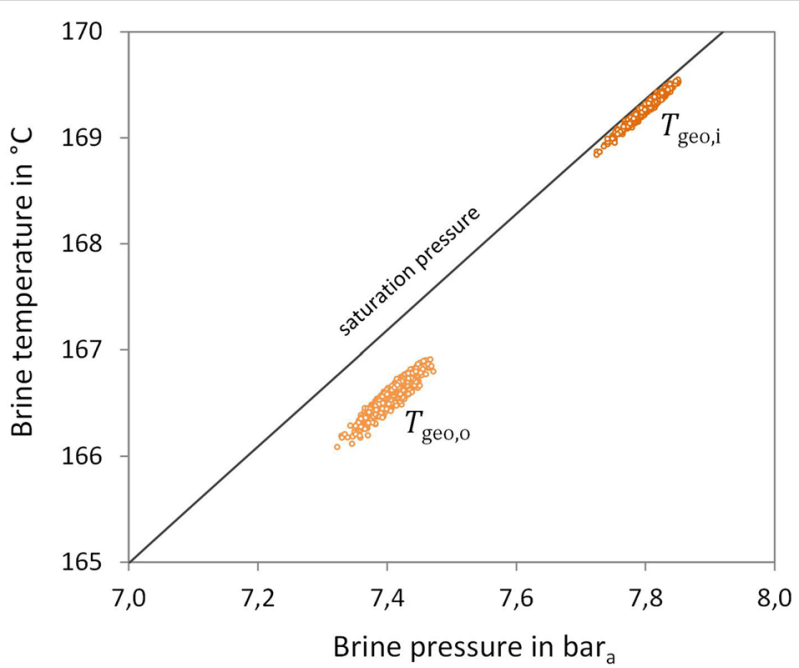

Fig. 9 Plant data for $48 \mathrm{~h}$ operation - brine supply temperatures and pressures in relation to the saturation pressure of water

The model uses the hot water and cooling water supply parameters (temperature and volumetric flow) as input values. Furthermore the degree of superheating of the working fluid vapor after the evaporator is an input parameter. Superheating can occur in case the evaporator tube bundle is not fully flooded with liquid working fluid. The liquid level in the evaporator depends on the operating conditions. For example, a lower liquid level results from higher hot water cycle temperatures.

The flow diagram of the numerical model is shown in Fig. 10.

The isentropic turbine efficiency has been adapted based on operational data. In Table 4 the used plant data and the resulting isentropic efficiency are shown. For each operating point, the isentropic efficiency leading to the least root means square error between modelled and real plant data has been selected. The used instrumentation is shown in Fig. 11. Sensor data are listed in Table 5. Based on this data the isentropic 
Table 3 Description of the modeled plant components

\begin{tabular}{|c|c|}
\hline Component & Description \\
\hline Evaporator & 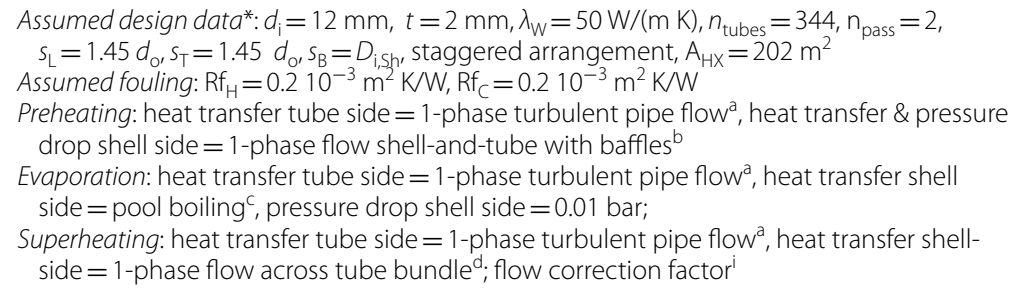 \\
\hline Recuperator & $\begin{array}{l}\text { Assumed design data }: \mathrm{d}_{\mathrm{i}}=24.4 \mathrm{~mm}, \mathrm{t}=2 \mathrm{~mm}, \lambda_{\mathrm{W}}=50 \mathrm{~W} /(\mathrm{m} \mathrm{K}), \mathrm{n}_{\text {tubes }}=26, \mathrm{n}_{\text {pass }}=4, \\
\mathrm{~s}_{\mathrm{F}}=3.18 \mathrm{~mm}, \delta_{\mathrm{F}}=0.4 \mathrm{~mm}, \mathrm{~h}_{\mathrm{F}}=8.3 \mathrm{~mm}, \lambda_{\mathrm{F}}=500 \mathrm{~W} /(\mathrm{m} \mathrm{K}) \text {, inline arrangement, } \\
\mathrm{A}_{\mathrm{HX}}=478 \mathrm{~m}^{2} \\
\text { Assumed fouling: } \mathrm{Rf}_{\mathrm{H}}=0.1810^{-3} \mathrm{~m}^{2} \mathrm{~K} / \mathrm{W}, \mathrm{Rf}_{\mathrm{C}}=0.110^{-3} \mathrm{~m}^{2} \mathrm{~K} / \mathrm{W} \\
\text { Heat transfer: heat transfer \& pressure drop tube side }=1 \text {-phase turbulent pipe flow }{ }^{\mathrm{a}, \mathrm{f}} \text {, heat } \\
\text { transfer \& pressure drop shell side }=1 \text {-phase flow across finned-tube bundles }{ }^{\mathrm{e}, \mathrm{g}} \text {, flow } \\
\text { correction factor for crossflow }\end{array}$ \\
\hline Condenser & $\begin{array}{l}\text { Assumed design data*: } \mathrm{d}_{\mathrm{i}}=14.8 \mathrm{~mm}, \mathrm{t}=1.6 \mathrm{~mm}, \lambda_{\mathrm{W}}=50 \mathrm{~W} /(\mathrm{m} \mathrm{K}), \mathrm{n}_{\text {tubes }}=672, \\
\mathrm{~A}_{\mathrm{HX}}=551 \mathrm{~m}^{2} \\
\text { Assumed fouling: } \mathrm{Rf}_{\mathrm{C}}=0.1710^{-3} \mathrm{~m}^{2} \mathrm{~K} \mathrm{~W} \\
\text { Heat transfer: heat transfer tube side }=1 \text {-phase turbulent pipe flow }{ }^{\mathrm{a}} \text {, heat transfer shell } \\
\text { side }=\text { condensation on horizontal tube bundle }{ }^{\mathrm{h}} \text {, pressure drop shell side }=0.01 \text { bar; } \\
\text { flow correction factor }\end{array}$ \\
\hline Dry cooler & $\begin{array}{l}\text { Assumed design data }: d_{\mathrm{i}}=11 \mathrm{~mm}, t=1.6 \mathrm{~mm}, \lambda_{\mathrm{W}}=50 \mathrm{~W} /(\mathrm{m} \mathrm{K}), n_{\text {pass }}=1, n_{\text {rows }}=5, \mathrm{~s}_{\mathrm{L}}=2.3 \\
d_{\mathrm{O}}, \mathrm{s}_{\mathrm{T}}=2.0 d_{\mathrm{O}}, \mathrm{s}_{\mathrm{F}}=2.65 \mathrm{~mm}, \delta_{\mathrm{F}}=0.25 \mathrm{~mm}, \mathrm{~h}_{\mathrm{F}}=8.3 \mathrm{~mm}, \lambda_{\mathrm{F}}=140 \mathrm{~W} /(\mathrm{m} \mathrm{K}) \text {, staggered } \\
\text { arrangement, } A_{\mathrm{V}} / \mathrm{A}_{\mathrm{C}}=0.25, A_{\mathrm{C}}=120 \mathrm{~m}^{2} ; \eta_{\mathrm{el}, \mathrm{V}}=0.75 \\
\text { Heat transfer: heat transfer tube side }=1 \text {-phase turbulent pipe flow }{ }^{\mathrm{a}} \text {, heat transfer air } \\
\text { side }=1 \text {-phase flow across finned-tube bundle }{ }^{\mathrm{e}, \mathrm{g}}\end{array}$ \\
\hline Turbogenerator & $\begin{array}{l}\text { Model: Nozzle stage }=\text { Laval-nozzle with constant minimum cross-section, } \\
\text { turbine wheel }=\text { variable isentropic efficiency } \\
\text { Assumed design data*: } \eta_{\mathrm{is}, \mathrm{T}}=0.75, \eta_{\mathrm{el}, \mathrm{TG}}=0.85 ; \mathrm{A}_{\mathrm{noz}}=2260 \mathrm{~mm}^{2} \\
\text { Operational data: variable } \eta_{\mathrm{is}, \mathrm{T}} \text { based plant data evaluation (see Fig. 14), }\end{array}$ \\
\hline Working fluid pump & Pressures and volume flow rate from process calculation; $\eta_{\mathrm{el}, \mathrm{P}}=0.8, \eta_{\mathrm{is}, \mathrm{P}}=0.75$ \\
\hline $\begin{array}{l}\text { Hot water and cool- } \\
\text { ing water pump }\end{array}$ & Power consumption characteristic based on real data as a function of volumetric flow rate \\
\hline \multicolumn{2}{|c|}{ * Design data and assumed data based on the manufacturer's documentation } \\
\hline \multicolumn{2}{|c|}{ a Nusselt-correlation acc. to Gnielinski, VDI Gesellschaft (2010), section G1 } \\
\hline \multicolumn{2}{|c|}{ b Design calculation acc. to Gaddis and Gnielinski, VDI Gesellschaft (2010), section G8 } \\
\hline \multicolumn{2}{|c|}{ c Heat flux calculation acc. to Gorenflo and Kenning, VDI Gesellschaft (2010), section H2 } \\
\hline \multicolumn{2}{|c|}{ d Nusselt-correlation acc. to Gnielinski, VDI Gesellschaft (2010), section G7 } \\
\hline \multicolumn{2}{|c|}{ e Nusselt-correlation acc. to Schmidt, VDI Gesellschaft (2010), section M1 } \\
\hline \multicolumn{2}{|c|}{ f Drag coefficient-correlation acc. to Blasius, VDI Gesellschaft (2010), section L1.1 } \\
\hline \multicolumn{2}{|c|}{ g Drag coefficient-correlation acc. to Gaddis, VDI Gesellschaft (2006), section L1.4 } \\
\hline \multicolumn{2}{|c|}{ h Nusselt-correlation acc. to Nusselt, VDI Gesellschaft (2010), section J1 } \\
\hline ¿ Flow correction facto & r acc. to Spang and Roetzel, VDI Gesellschaft (2010), s \\
\hline
\end{tabular}

turbine efficiency increases with increasing pressure difference across the turbine and has a best performance point that depends on the condensation pressure (Fig. 12).

From Figs. 13 and 14 it can be seen that the model gives a good representation of the plant operation. Despite the gross power, which is underestimated by about $3 \%$, all other values can be reproduced with good accuracy.

Using the numerical model the power output of the binary demonstration plant can be calculated for varying hot water and cooling water temperatures. In Fig. 15 the gross and net power output for a saturated vapor cycle is shown. The net power reaches a maximum depending on the cooling water inlet temperature and increases with higher hot water temperatures. In Fig. 16 (left) the power increase with increasing hot water inlet 


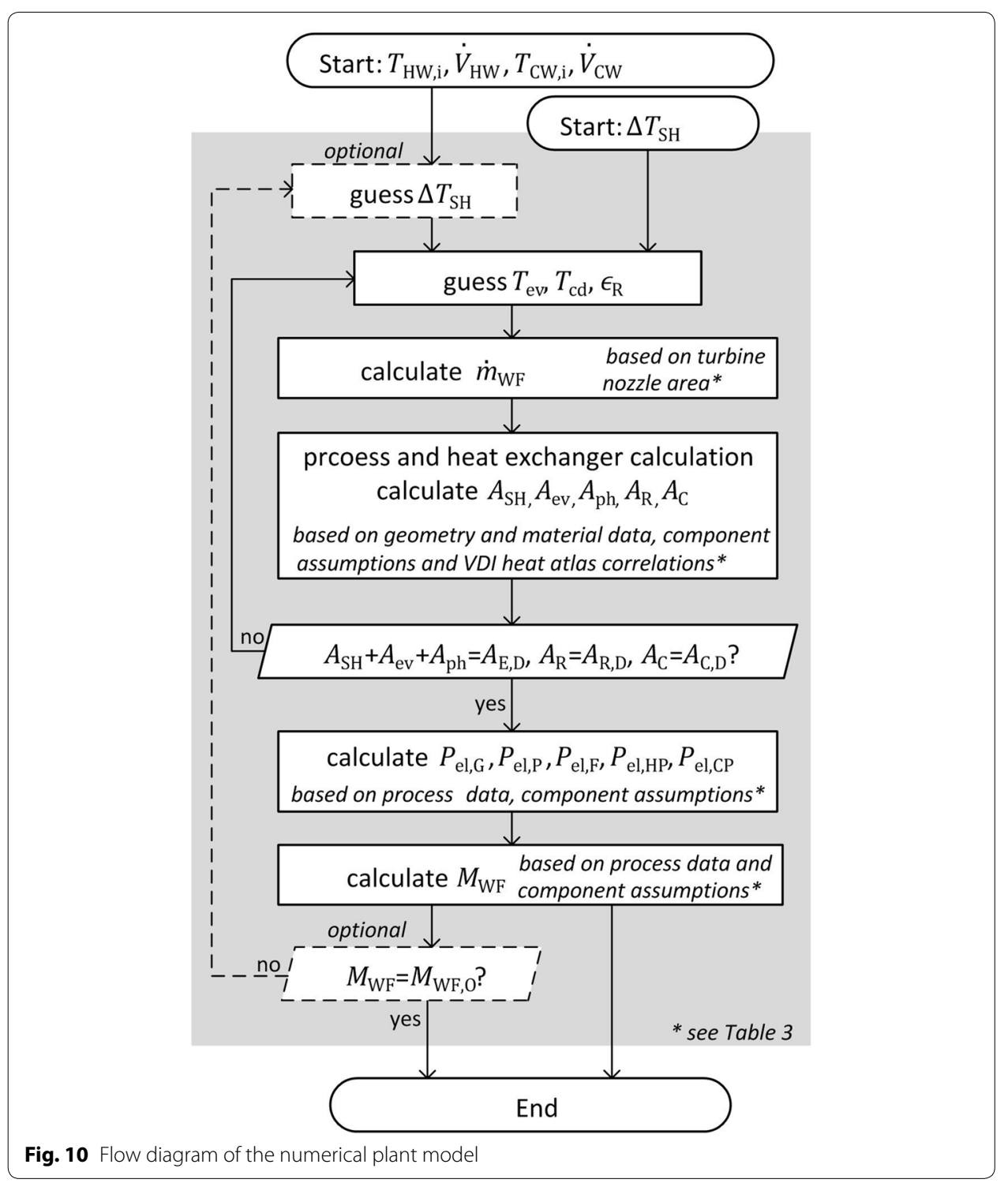

temperature is shown. In Fig. 16 (right) it can be seen that the working fluid mass in the ORC-unit that is necessary to realize a saturated vapor cycle also increases with the hot water temperature. This results from changing working fluid distribution in the n-pentane cycle and therefore also changing n-pentane liquid-level in the evaporator. Superheating occurs if the liquid-level in the evaporator is lower than the tube area.

In real operation, the binary demonstration power plant is operated with a constant working fluid mass. In this case, the degree of superheating increases with higher hot water temperatures since the liquid level in the evaporator decreases. The power estimate with constant working fluid mass is shown in Fig. 17. Due to the superheating, the power output is lower than the estimate for the saturated vapor cycle in Fig. 16. 


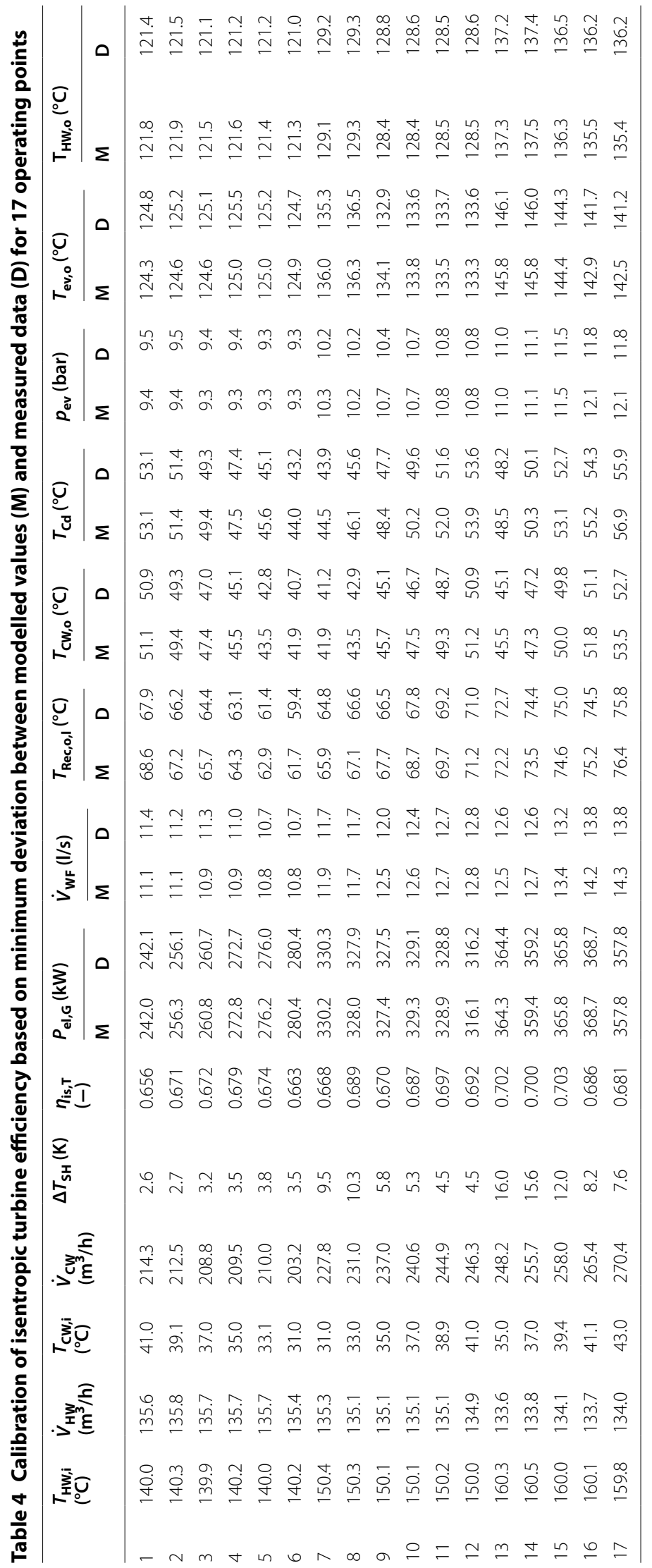




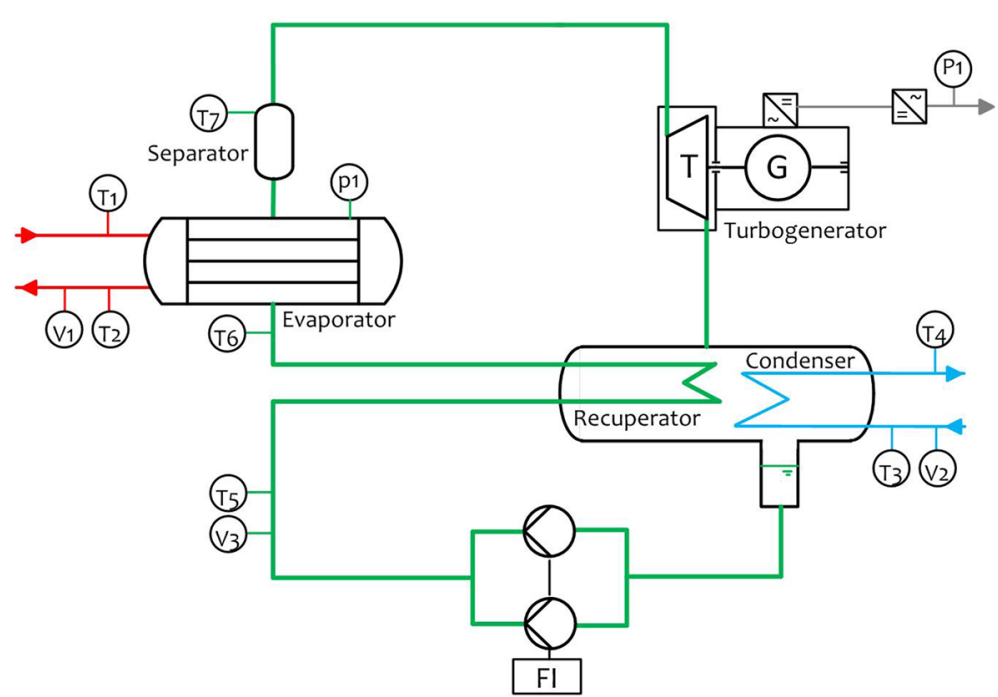

Fig. 11 ORC process diagram showing the used instrumentation

Table 5 Instrumentation and sensor data

\begin{tabular}{|c|c|c|}
\hline ID & Description & $\begin{array}{l}\text { 1: Measuring range; } 2 \text { : Sensor type } \\
\text { 3: Signal; 4: Measuring error }\end{array}$ \\
\hline $\mathrm{T} 1$ & Hot water inlet temperature $T_{\mathrm{HW}, \mathrm{i}}$ & $\begin{array}{l}\text { 1: } 0 \ldots 200^{\circ} \mathrm{C} ; 2: \text { Pt100; } 3: 4 \ldots 20 \mathrm{~mA} ; \\
\text { 4: acc. to DIN EN 60751, class B }\end{array}$ \\
\hline $\mathrm{T} 2$ & Hot water outlet temperature $T_{\mathrm{HW}, \mathrm{O}}$ & $\begin{array}{l}\text { 1: } 0 \ldots 200^{\circ} \mathrm{C} ; 2: \text { Pt100; } 3: 4 \ldots 20 \mathrm{~mA} \text {; } \\
\text { 4: acc. to DIN EN 60751, class B }\end{array}$ \\
\hline $\mathrm{V} 1$ & Volumetric hot water flow rate $\dot{V}_{\mathrm{HW}}$ & $\begin{array}{l}\text { 1: } 0 \ldots 160 \mathrm{~m}^{3} / \mathrm{h} ; 2: \text { electromagnetic; } \\
3: 4 \ldots 20 \mathrm{~mA} ; 4: \pm 0.2 \% \text { of } \mathrm{MV}+1 \mathrm{~mm} / \mathrm{s}\end{array}$ \\
\hline T3 & Cooling water inlet temperature $T_{\mathrm{CW}, \mathrm{i}}$ & $\begin{array}{l}\text { 1: } 0 \ldots 100^{\circ} \mathrm{C} ; 2: \text { Pt100; 3: } 4 \ldots 20 \mathrm{~mA} ; \\
\text { 4: acc. to DIN EN 60751, class B }\end{array}$ \\
\hline $\mathrm{T} 4$ & Cooling water outlet temperature $T_{\mathrm{CW}, \mathrm{o}}$ & $\begin{array}{l}\text { 1: } 0 \ldots 100^{\circ} \mathrm{C} ; 2: \text { Pt100; } 3: 4 \ldots 20 \mathrm{~mA} ; \\
\text { 4: acc. to DIN EN 60751, class B }\end{array}$ \\
\hline \multirow[t]{2}{*}{ V2 } & Volumetric hot cooling flow rate $\dot{V}_{\mathrm{KW}}$ & $\begin{array}{l}\text { calculated value from cooling water pump } \\
\text { speed due to problems with MID-meas- } \\
\text { urement }\end{array}$ \\
\hline & Superheating of the working fluid vapor $\Delta T_{S H}$ & $\begin{array}{l}\text { calculated based on measured data for } T_{\text {ev,o }} \\
\text { and } p_{\text {ev }} \text { using thermophysical properties } \\
\text { with NIST database }\end{array}$ \\
\hline T5 & Condensation temperature $T_{\mathrm{Cd}}$ & $\begin{array}{l}\text { 1: } 0 \ldots 150^{\circ} \mathrm{C} ; 2: \text { Pt100; } 3: 4 \ldots 20 \mathrm{~mA} ; \\
\text { 4: acc. to DIN EN 60751, class B }\end{array}$ \\
\hline T6 & Liquid temperature recuperator outlet $T_{\text {Rec,o,l }}$ & $\begin{array}{l}\text { 1: } 0 \ldots 150^{\circ} \mathrm{C} ; 2: \text { Pt100; } 3: 4 \ldots 20 \mathrm{~mA} ; \\
\text { 4: acc. to DIN EN 60751, class B }\end{array}$ \\
\hline $\mathrm{T} 7$ & Outlet temperature evaporator $\mathrm{T}_{\mathrm{ev}, \mathrm{o}}$ & $\begin{array}{l}\text { 1: } 0 \ldots 150^{\circ} \mathrm{C} ; 2: \text { Pt100; } 3: 4 \ldots 20 \mathrm{~mA} ; \\
\text { 4: acc. to DIN EN 60751, class B }\end{array}$ \\
\hline p1 & Evaporator pressure $p_{\mathrm{ev}}$ & $\begin{array}{l}\text { 1: } 0 \ldots 20 \mathrm{bar} ; 2: 4 \ldots 20 \mathrm{~mA} ; 3 \text { : ceramic sensor; } \\
4: 0.5 \% \text { of } \mathrm{NV}\end{array}$ \\
\hline V3 & Volumetric working fluid flow rate $\dot{V}_{W F}$ & $\begin{array}{l}\text { 1: } 0 \ldots 150 \mathrm{~L} / \mathrm{min} ; 2: \text { ultrasonic; } 3: 4 \ldots 20 \mathrm{~mA} \\
4: \pm 0.3 \% \text { of } \mathrm{MV}\end{array}$ \\
\hline P1 & Gross power $P_{\mathrm{el}, \mathrm{G}}$ & $\begin{array}{l}\text { 1: }-10 \ldots 600 \mathrm{~kW} ; 2: \text { power meter; } 3: 4.20 \mathrm{~mA} \\
4: \pm(0.5 \% \text { of } \mathrm{NV}+1 \text { digit })\end{array}$ \\
\hline
\end{tabular}

$M V$ measured value, $N V$ nominal value 


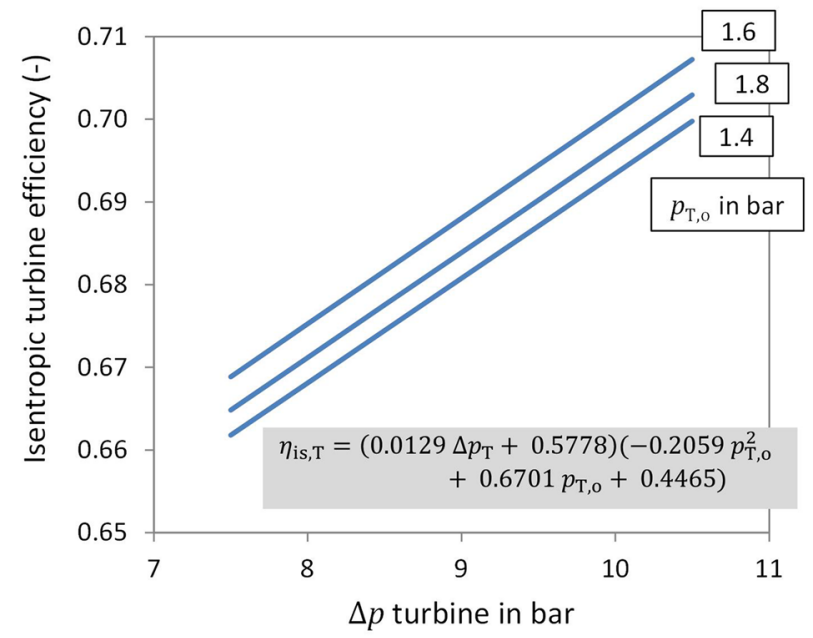

Fig. 12 Isentropic turbine efficiency estimate derived from real plant data

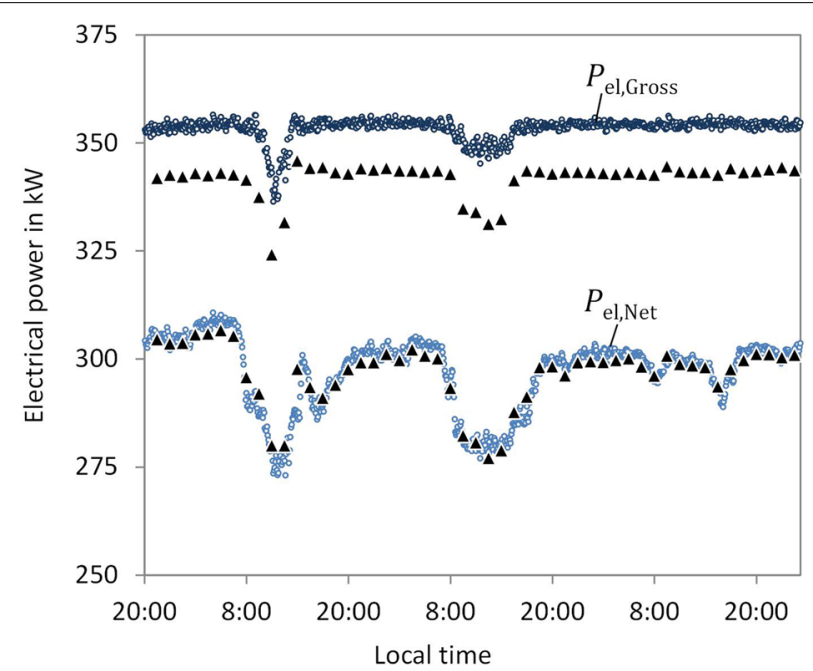

Fig. 13 Gross and net power output_comparison of modeled and real plant data for Plant data for $48 \mathrm{~h}$ operation

\section{Conclusions}

The presented technical concept was developed to produce power from a small temperature difference in order to avoid scaling and to preserve the possibility of hot reinjection. Another aspect for the technical concept was the integration of a fully automatic binary plant at an already existing geothermal site. Within this paper the feasibility of this technical concept has been shown.

The presented technical concept integrates an Organic Rankine Cycle unit using an intermediary hot water and cooling water cycle. Even though the net power output is decreased by using intermediary cycles, the technical and organizational advantages explained in the paper prevailed. The operational phase has even shown that the demonstration plant could not be operated without an intermediate hot water cycle. Due to changing well (operating) conditions the binary plant is supplied with two-phase 


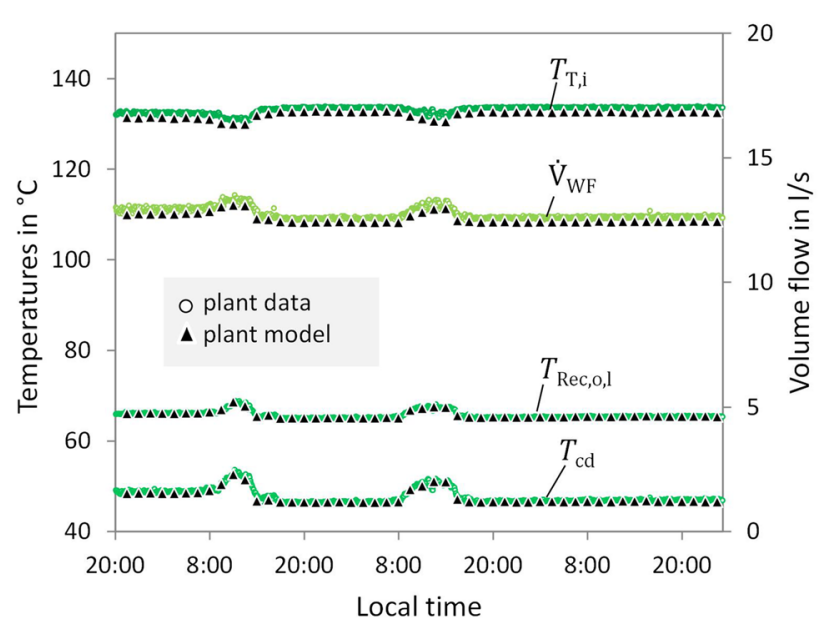

Fig. $14 \mathrm{~N}$-pentane temperatures and volumetric flow-comparison of modeled and real plant data for Plant data for 48 h operation
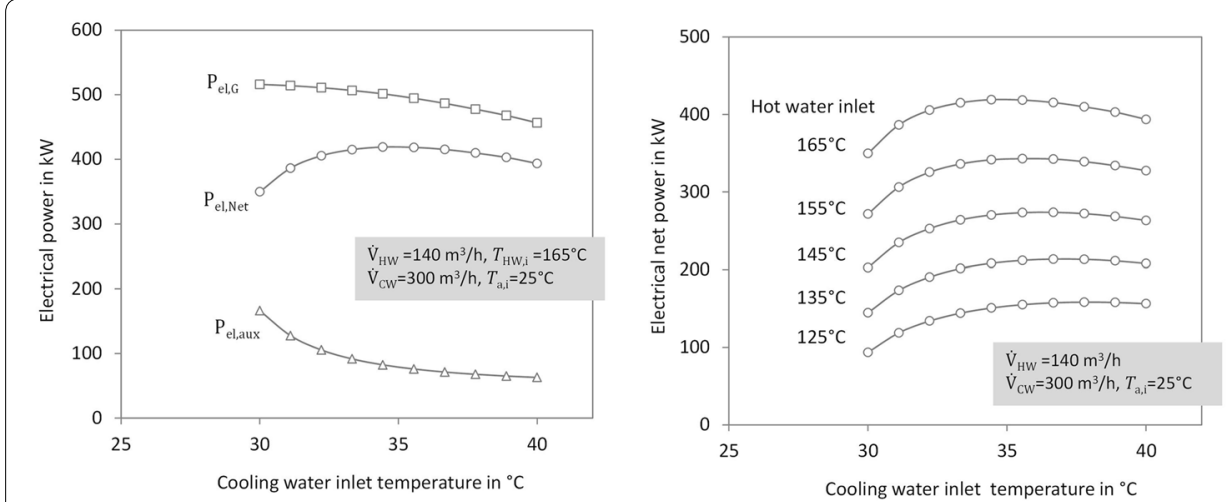

Fig. 15 Estimated generator power, net power and auxiliary power (left) and net power for different hot water inlet temperatures (right) depending on the cooling water temperature
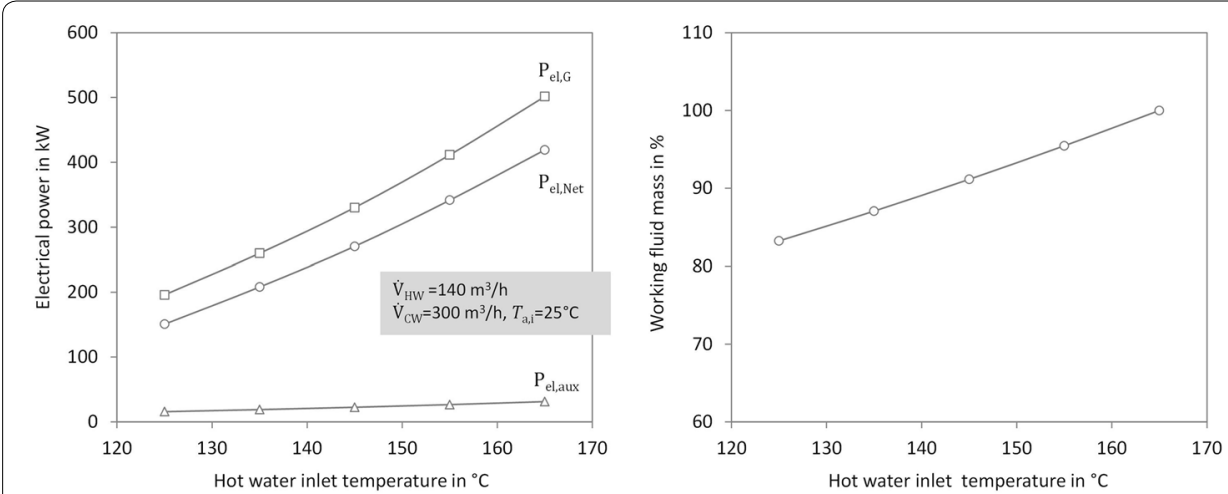

Fig. 16 Estimated generator power, net power and auxiliary power (left) and working fluid mass (right) depending on the hot water temperature 

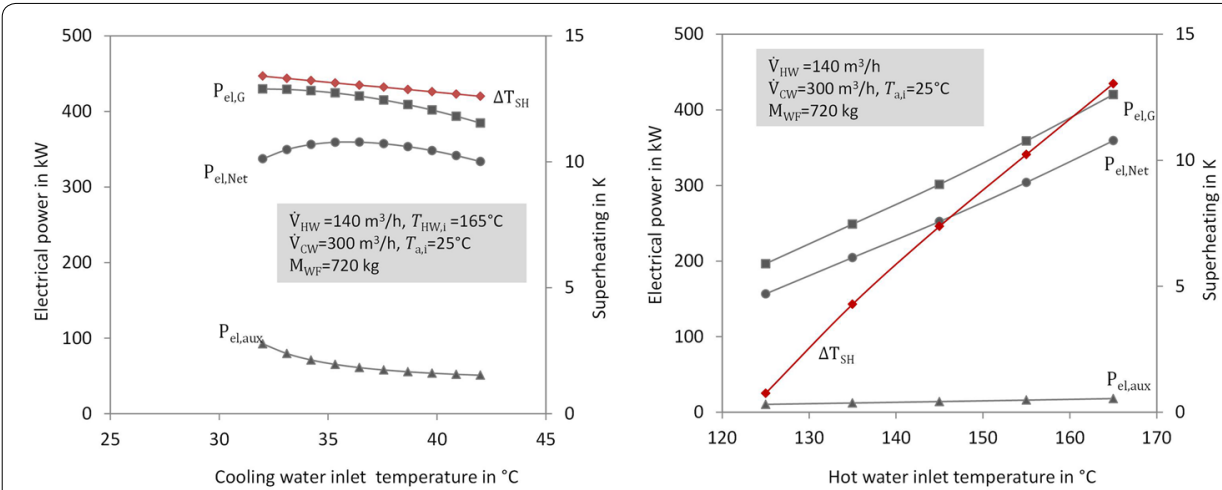

Fig. 17 Estimated generator power, net power, auxiliary power and superheating depending on the cooling water temperature (left) and the hot water temperature (right)

flow instead of pure liquid, as previously designed. It can be concluded that intermediate cycles, especially the hot water cycle, are interesting technical solutions that can be applied to other projects. However, cost reduction potentials (e.g. decreasing expansion vessel size or using thermal oil instead of water) should be evaluated.

Besides high ambient humidity, the availability of the electrical grid is the largest technical challenge for the operation of the demonstration plant. The binary plant has been designed for grid-parallel operation and is not capable of electrical island mode operation. As a result of power outages and phase failure, the plant has experienced over 130 plant stops and starts until now. Due to technical modifications an automatic re-start is now possible for various situations. For the future it is planned to change the grid connection point in order to connect to a more stable electrical grid. A modification of the ORC-unit for grid-parallel and island operation would be technically possible but is much more costly.

The plant is currently operated with limited power by controlling the hot water supply temperature to the ORC-unit in order to meet the consumption of the injection pumps nearby. Real plant data for typical operation are shown in "Results and discussion" section. Due to the technical concept it is possible to adapt the plant operation in order to realize low auxiliary power consumption at different operating conditions. Due to the operation at off-design conditions, the maximum proven gross power until now is $400 \mathrm{~kW}$.

Using the presented numerical plant model which incorporates detailed component data and was validated with measured plant values, it can be shown that the rated capacity of $500 \mathrm{~kW}$ can be reached when the working fluid mass in the ORC unit is sufficient to realize a saturated vapor cycle. Technical and operational solutions in order to adapt the working fluid mass to different operating conditions will be investigated in the future.

\footnotetext{
Abbreviations

$A_{C}$ : calculated heat transfer area condenser in $\mathrm{m}^{2} ; A_{C, D}$ : design heat transfer area condenser in $\mathrm{m}^{2} ; A_{C O}$ : effective crossflow area dry cooler in $\mathrm{m}^{2} ; A_{E, D}$ : design heat transfer area evaporator in $\mathrm{m}^{2} ; A_{\text {ev }}$ : calculated heat transfer area evaporation in $\mathrm{m}^{2} ; A_{\text {noz: }}$ total minimum cross section of the nozzle stage in $\mathrm{mm}^{2} ; A_{\mathrm{ph}}$ : calculated heat transfer area preheating in $\mathrm{m}^{2}$; $A_{S H}$ : calculated heat transfer area superheating in $\mathrm{m}^{2} ; A_{\mathrm{R}}$ : calculated heat transfer area recuperator in $\mathrm{m}^{2} ; A_{\mathrm{R}, \mathrm{D}}$ : design heat transfer area recuperator in $\mathrm{m}^{2} ; A_{\sqrt{V}} / A_{C}$ : ratio of free cross section at the fan to effective cross flow area; $C W C$ : cooling water cycle; $d_{\mathrm{i}}$ : inner tube diameter in $\mathrm{mm} ; D_{\mathrm{i}, \text { Sh}}$ : inner shell diameter in $\mathrm{mm}$; $d_{0}$ : outer tube diameter in $\mathrm{mm} ; h_{\mathrm{F}}$ : fin height
} 
in $\mathrm{mm}$; HE: heat exchanger; HWC: hot water cycle; $m_{\mathrm{a}}$ : air mass flow rate in $\mathrm{kg} / \mathrm{s} ; m_{\mathrm{geo}}$ : brine mass flow rate in $\mathrm{kg} / \mathrm{s} ; m_{\mathrm{CW}}$ : cooling water mass flow rate in $\mathrm{kg} / \mathrm{s} ; m_{H}$ : hot water mass flow rate to ORC-unit in $\mathrm{kg} / \mathrm{s} ; m_{\mathrm{WF}}$ : working fluid mass flow rate in $\mathrm{kg} / \mathrm{s} ; M_{\mathrm{WF}}$ : working fluid mass ORC-unit in $\mathrm{kg} ; M_{\mathrm{WF}, 0}$ : operational working fluid mass ORC-unit in $\mathrm{kg}$; $n_{\text {tubes: }}$ number of tubes; $n_{\text {pass: }}$ number of tube side flow passes; $n_{\text {rows }}$ : number of tube rows ORC Organic Rankine Cycle; $P_{\text {elaux: }}$ electrical auxiliary power in $\mathrm{kW} ; P_{\text {el,ccp }}$ electrical power cooling water pump in $\mathrm{kW} ; P_{\mathrm{el}, \mathrm{Hp}}$ : electrical power hot water pump in $\mathrm{kW}$; $P_{\mathrm{el}, \mathrm{F}}$ : electrical power dry cooler fans in $\mathrm{kW} ; P_{\mathrm{el}, G}$ : electrical power generator in $\mathrm{kW} ; P_{\mathrm{el}, \mathrm{G}}$ : electrical power feed-in unit (gross power) in $\mathrm{kW} ; P_{\text {el, Net: }}$ electrical net power in $\mathrm{kW} ; P_{\text {el, }}$ : electrical power working fluid pump in $\mathrm{kW} ; p_{\text {ev }}$ : evaporation pressure working fluid in bar; $p_{\mathrm{T}, \text { : }}$ turbine outlet pressure working fluid in bar; $\mathrm{Rf}_{,}$: fouling factor cold fluid side in $\mathrm{m}^{2} \mathrm{~K} / \mathrm{W} ; \mathrm{Rf}_{,}$: fouling factor hot fluid side in $\mathrm{m}^{2} \mathrm{~K} / \mathrm{W} ; \mathrm{s}_{\mathrm{B}}$ : baffle spacing in $\mathrm{mm}$; $\mathrm{s}_{\mathrm{F}}$ : fin spacing in $\mathrm{mm}$; $\mathrm{s}_{1}$ : longitudinal tube pitch in $\mathrm{mm}$; $s_{\mathrm{T}}$ : transversal tube pitch in $\mathrm{mm}$; $t$ : wall thickness in $\mathrm{mm}$; $t_{\mathrm{F}}$ : fin thickness in $\mathrm{mm} ; \mathrm{T}_{\mathrm{a}, \mathrm{i}}$ : air inlet temperature to dry cooler in ${ }^{\circ} \mathrm{C}_{i} T_{\text {a,o }}$ : air outlet temperature from dry cooler in ${ }^{\circ} \mathrm{C}_{i} T_{c d}$ : condensation temperature working fluid in ${ }^{\circ} \mathrm{C}_{;} T_{\mathrm{C}}$; : cooling water inlet temperature to ORC-unit in ${ }^{\circ} \mathrm{C}_{i} T_{\mathrm{CW}, 0}$ : cooling water outlet temperature from ORC-unit in ${ }^{\circ} \mathrm{C}_{;} T_{\text {ev }}$ : evaporation temperature working fluid in ${ }^{\circ} \mathrm{C}_{i} T_{\text {evo, }}$ : evaporator outlet temperature working fluid in ${ }^{\circ} \mathrm{C}_{i} T_{\mathrm{HW} ;}$ : hot water inlet temperature to ORC-unit in ${ }^{\circ} \mathrm{C} ; T_{\mathrm{HW}, 0}$ : hot water outlet temperature from ORC-unit in ${ }^{\circ} \mathrm{C}_{;} T_{\text {geo, }}$; $:$ brine inlet temperature to primary heat exchanger in ${ }^{\circ} \mathrm{C}_{i} T_{\text {geo,o, }}$ : brine outlet temperature from primary heat exchanger in ${ }^{\circ} \mathrm{C}_{;} \mathrm{T}_{\text {Rec,o, }}$ : recuperator outlet temperature working fluid liquid in ${ }^{\circ} \mathrm{C} ; \Delta T_{\mathrm{CW}}$ : temperature difference cooling water outlet and inlet in $\mathrm{K} ; \Delta T_{\mathrm{TTD}}$ : initial temperature difference in $K_{;} \Delta T_{\text {ITD,op }}$ : optimum initial temperature difference for maximum net power in $K_{;} \Delta T_{S H}$ : superheating for working fluid vapor in $\mathrm{K}$; $\Delta p$ : pressure difference in bar; $\dot{V}_{c w}$ : cooling water volume flow rate in $\mathrm{m}^{3} / \mathrm{h}$; $\dot{V}_{\text {HW: }}$ hot water volume flow rate to ORC-unit in $\mathrm{m}^{3} / \mathrm{h} ; \dot{V}_{\text {HW,ORC: }}$ hot water volume flow rate to ORC-unit in $\mathrm{m}^{3} / \mathrm{h} ; \dot{V}_{\mathrm{HW} \text {.PHE: }}$ hot water mass flow rate to primary heat exchanger in $\mathrm{m}^{3} / \mathrm{h} ; \dot{V}_{\mathrm{WF}}$ : working fluid volume flow rate in $\mathrm{l} / \mathrm{s} ; \epsilon_{\mathrm{R}}$ : effectiveness

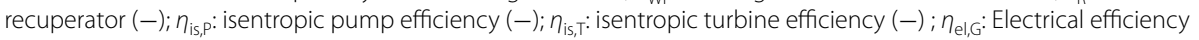
generator and feed-in unit (-); $\eta_{\text {el, }}$ : electrical pump efficiency $(-) ; \eta_{\text {el, }}$ : electrical fan efficiency $(-) ; \lambda_{F}$ : heat conductivity fin in $\mathrm{W} /(\mathrm{m} \mathrm{K}) ; \lambda_{\mathrm{W}}$ : heat conductivity tube wall in $\mathrm{W} /(\mathrm{m} \mathrm{K})$.

\section{Acknowledgements}

We thank the Agency for the Assessment and Application of Technology (BPPT) and Pertamina Geothermal Energy (PGE) for good cooperation. We thank PT. Intan Kalorindo and Dürr Cyplan for their collaboration and support. The authors also thank the reviewers and the Editor, whose suggestions improved the final version of this work.

\section{Authors' contributions}

SF and SK have specified the plant concept and technical components. SF developed the plant model and evaluated the operational data. SF was a major contributor in writing the manuscript. SK summarized the operating experience, evaluated the plant data and validated the model. GK was a major contributor in writing the manuscript. All authors read and approved the final manuscript.

\section{Funding}

We thank the German Federal Ministry for Education and Research (BMBF) for funding this project (Grant 03G0834A).

\section{Availability of data and materials}

The datasets used and/or analysed during the current study are available from the corresponding author on reasonable request.

\section{Competing interests}

The authors declare that they have no competing interests.

Received: 7 May 2019 Accepted: 23 September 2019

Published online: 12 October 2019

\section{References}

Agahi R, Valdimarsson P. Field Performance Evaluation of the Largest Geothermal Organic Rankine Cycle Plant. In: Proceedings World Geothermal Congress 2015, Melbourne, Australia 19-25 April 2015.

Astolfi M, Xodo L, Romano MC, Macchi E. Technical and economical analysis of a solar-geothermal hybrid plant based on an Organic Rankine Cycle. Geothermics. 2011;40(1):58-68.

Astolfi M, Romano MC, Bombarda P, Macchi E. Binary ORC (Organic Rankine Cycles) power plants for the exploitation of medium-low temperature geothermal sources_Part B: techno-economic optimization. Energy. 2014;66:435-46.

Astolfi M, Noto La Diega L, Romano M C, Merlo U, Filippini S, Macchi E. Techno-economic optimization of a geothermal ORC with novel "Emeritus" heat rejection units in hot climates. Renewable Energy 2019. (in press).

Brehme M, Moeck I, Kamah Y, Zimmermann G, Sauter M. A hydrotectonic model of a geothermal reservoir - a study in Lahendong, Indonesia. Geothermics. 2014;51:228-39.

Brehme M, Deon F, Haase C, Wiegand B, Kamah Y, Sauter M, Regenspurg S. Fault controlled geochemical properties in Lahendong geothermal reservoir Indonesia. Grundwasser. 2016a;21(1):29-41.

Brehme M, Blöcher G, Cacace M, Kamah Y, Zimmermann G, Sauter M. Permeability distribution in the Lahendong geothermal field: a blind fault captured by thermal-hydraulic simulation. Environ Earth Sci. 2016b;75(1088):1-11.

Bronicki LY. Geothermal power stations. In: Kaltschmitt A, editor. Renewable energy systems. New York: Springer; 2013.

Budisulistyo D, Wong CS, Krumedieck S. Lifetime design strategy for binary geothermal plants considering degradation of geothermal resource productivity. Energy Convers Manage. 2017;132:1-13.

Cataldo F, Mastrullo R, Mauro AW, Vanoli GP. Fluid selection of organic rankine cycle for low-temperature waste heat recovery based on thermal optimization. Energy. 2014;72:159-67.

Darma S. Indonesia: Vast geothermal potential, modest but growing exploitation. In: DiPippo, ed. Geothermal power generation—developments and innovation, Elsevier; 2016. 
DiPippo. Geothermal power plants_-principles, applications, case studies and environmental impact, 4th edition, Butterworth-Heinemann; 2015.

Erbas K, Jaya M, Jousset P, Deon F, Rachmat Sule, Frick S, Huenges E, Bruhn D. German-Indonesian Cooperation on Sustainable Geothermal Energy Development in Indonesia—Status and Perspectives. In: Proceedings World Geothermal Congress 2015, Melbourne, Australia 19-25 April 2015.

Franco A. Power production from a moderate temperature geothermal resource with regenerative Organic Rankine Cycles. Energy Sustain Dev. 2011;15(4):411-9.

Frick S, Saadat A, Taufan S, Eben E, Kupfermann A, Erbas K, Huenges E, Mawardi A. Geothermal binary power plant for Lahendong, Indonesia: A German-Indonesian Collaboration Project. In: Proceedings World Geothermal Congress 2015, Melbourne, Australia, 19-25 April 2015.

Gabbrielli R. A novel design approach for small scale low enthalpy binary geothermal power plants. Energy Convers Manage. 2012;64:263-72.

Gao H, Liu C, He C, Xu X, Wu S, Li Y. Performance analysis and working fluid selection of a supercritical organic rankine cycle for low grade waste heat recovery. Energies. 2012;5(9):3233-47.

Heberle F, Jahrfeld T, Brüggemann D. Thermodynamic analysis of double-stage organic Rankine cycles for low-enthalpy sources based on a case study for 5.5 MWe Power Plant Kirchstockach (Germany). In: Proceedings World Geothermal Congress 2015, Melbourne, Australia 19-25 April 2015.

Hettiarachchi MHD, Golubovic M, Worek WM, Ikegami Y. Optimum design criteria for an Organic Rankine cycle using lowtemperature geothermal heat sources. Energy. 2007;32(9):1698-706.

Koestono H, Eben Ezer, Marihot S, Hijalti F. Geothermal Model of the Lahendong Geothermal Field, Indonesia. In: Proceedings World Geothermal Congress 2010. Bali, Indonesia 25-29 April 2010.

Lakew AA, Bolland O. Working fluids for low-temperature heat source. Appl Therm Eng. 2010;30(10):1262-8.

Li Y-R, Du M-T, Wu C-M, Wu S-Y, Liu C, Xu J-L. Economical evaluation and optimization of subcritical organic Rankine cycle based on temperature matching analysis. Energy. 2014;68:238-47.

Manente G, Field R, DiPippo R, Tester J. Hybrid Solar-Geothermal Power Generation to Increase the Energy Production from a Binary Geothermal Plant. In: Proceedings of the ASEM 2011 International Mechanical Engineering Congress \& Exposition. Denver, Colorado; 2011.

Maraver D, Royo J, Lemort V, Quoilin S. Systematic optimization of subcritical and transcritical organic Rankine cycles (ORCs) constrained by technical parameters in multiple applications. Appl Energy. 2014;117:11-29.

Noorollahi Y, Itoi R. Production capacity estimation by reservoir numerical simulation of northwest (NW) Sabalan geothermal field, Iran. Energy. 2011;36(7):4552-69.

Nugroho, Andi J. Evaluation of waste brine utilization from LHD unit III for electricity generation in Lahendong geothermal field, Indonesia. In: United Nations University Geothermal Training program Reports 2007, Number 17, 2007.

Quloilin S. Sustainable energy conversion through the use of organic rankine cycles for waste heat recovery and solar applications. Dissertation, University of Liège (Belgium); 2011.

Richter A. First 110 MW unit of Sarulla Geothermal Plant starts operation. http://www.thinkgeoenergy.com/first-1 10-mwunit-of-sarulla-geothermal-plant-starts-operation/.2018a. Accessed 23 July 2018.

Richter A. Indonesia expects an addition of 255 MW geothermal capacity in 2018. http://www.thinkgeoenergy.com/ indonesia-expects-an-addition-of-255-mw-geothermal-capacity-in-2018/.2018b. Accessed 23 July 2018.

Sanyal S, Kitz K, Glaspey D. Optimization of Power Generation from Moderate Temperature Geothermal Systems-A Case History. In: Proceedings of the World Geothermal Congress. Antalya, Turkey; 2005.

Shengjun Z, Huaixin W, Tao G. Performance comparison and parametric optimization of subcritical Organic Rankine Cycle (ORC) and transcritical power cycle system for low-temperature geothermal power generation. Appl Energy. 2011;88(8):2740-54

Toffolo A, Lazzaretto A, Manente G, Paci M. A multi-criteria approach for the optimal selection of working fluid and design parameters in Organic Rankine Cycle systems. Appl Energy. 2014;121:219-32.

Usman M, Imran M, Yang Y, Lee DH, Park B-S. Thermo-economic comparison of air-cooled and cooling tower based Organic Rankine Cycle (ORC) with R245fa and R1233zde as candidate working fluids for different geographical climate conditions. Energy. 2017;123:353-66.

VDI Gesellschaft, ed. VDI Wärmeatlas. Springer; 2006.

VDI Gesellschaft, ed. VDI Heat Atlas. Springer; 2010.

Walraven D, Laenen B, D'haeseleer W. Optimum configuration of shell-and-tube heat exchangers for the use in lowtemperature organic Rankine cycles. Energy Convers Manage. 2014;83:177-87.

Wendt D, Mines G. Interim Report: Air-Cooled Condensers for Next Generation Geothermal Power Plants Improved Binary Cycle Performance. DOE Report, September, 42. 2010. http://www.inl.gov/technicalpublications/Docum ents/4886682.pdf.

Wolf N, Gabbay A. Sarulla 330 MW Geothermal Project—Key success factors in development. In: Proceedings World Geothermal Congress 2015 Melbourne, Australia, 19-25 April 2015.

\section{Publisher's Note}

Springer Nature remains neutral with regard to jurisdictional claims in published maps and institutional affiliations. 